\title{
Inguinal hernia containing an incarcerated ureter of a transplanted kidney
}

\author{
Luka Filipović-Grčicić ${ }^{1,2}$ (D) , Neva Coce ${ }^{2}$ \\ ${ }^{1}$ Department of Radiology, University Hospital Centre Zagreb, Zagreb, Croatia \\ ${ }^{2}$ School of Medicine, University of Zagreb, Zagreb, Croatia
}

OPEN ACCESS

Correspondence:

Luka Filipovic-Grcic MD

luka.filipovicg@outlook.com

orcid.org/0000-0003-0024-8359

This article was submitted to RAD CASA - Medical Sciences as the Case Report

Conflict of Interest Statement:

The authors declare that the research was conducted in the absence of any commercial or financial relationships that could be construed as a potential conflict of interest.

Received: 11 September 2019 Accepted: 25 October 2019 Published: 17 December 2019

Citation: Filipović-Grčić $L$ and Coce N. Inguinal hernia containing an incarcerated ureter of a transplanted kidney. RAD CASA - Medical Sciences. $540=48-49$ (2019): 75-77. https:// dx.doi.org/10.21857/yk3jwhrq39

Copyright (C) 2019 Filipović-Grčić and Coce. This is an open-access article distributed under the terms of the Creative Commons Attribution License (CC BY). The use, distribution

or reproduction in other forums is permitted, provided the original is permitted, provided the original au-

thor(s) and the copyright owners(s)
are credited and that the original are credited and that the original
publication in this journal is cited, in accordance whit accepted adacemic practice. No use, distribution or reproduction is permitted which does not comply with these terms.

\section{ABSTRACT:}

We presented a case of an inguinal hernia containing an incarcerated ureter in a patient with transplanted kidney. A 60-year-old man was admitted to hospital with elevated creatinine levels and trans-abdominal ultrasound recognised hydronephrosis. An unenhanced CT scan revealed an incarcerated ureter in the inguinal hernia sac. The imaging confirmed hydronephrosis of the enlarged kidney with dilated pyelon and calyces. Later control examinations reported no change of grade of hydronephrosis and kidney function, probably due to the intermittent nature of ureteral incarceration. We present this case in light of the recent increase in reporting of ureteroinguinal hernias and as a reminder to radiologists always to check the course of the ureters when they encounter or suspect inguinal hernia.

KEYWORDS: inguinal hernia, CT scan, ureteroinguinal hernia, incarcerated ureter, hydronephrosis

\section{SAŽETAK:}

INGVINALNA HERNIJA KOJA SADRŽI INKARCERIRANI URETER TRANSPLANTIRANOG BUBREGA U ovom radu prikazujemo slučaj pacijenta s transplantiranim bubregom koji je razvio ingvinalnu herniju sa inkarceriranim ureterom. Muškarac u dobi od 60 godina primljen je u bolnicu s povišenim kreatininom te transabdominalnim ultrazvukom otkrivenom hidronefrozom. Nativni CT pregled pokazao je inkarcerirani ureter u vreći ingvinalne hernije. Potvrđena je i hidronefroza uvećanog bubrega s dilatiranim pijelonom i kaliksima. Kasniji kontrolni pregledi utvrdili su stacionarnu hidronefrozu trećeg stupnja te očuvanu bubrežnu funkciju, vjerojatno uslijed intermitentne prirode inkarceracije. Ovaj prikaz donosimo potaknuti sve učestalijim prijavljivanjem slučajeva ureteroingvinalnih hernija posljednjih godina. Također, nadamo se da će ovaj rad poslužiti kao podsjetnik radiolozima da uvijek provjere tijek uretera pri pregledu ili sumnji na ingvinalnu herniju.

KLJUČNE RIJEČI: ingvinalna hernija, CT, ureteroingvinalna hernija, inkarcerirani ureter, hidronefroza 


\section{BACKGROUND}

Inguinal hernia is a relatively common medical condition where the contents of the abdominal cavity protrude through the inguinal canal. The prevalence of abdominal wall hernias for all ages is around $1.7 \%$, with inguinal hernias accounting for $75 \%$ of the cases ${ }^{1}$. Only $66 \%$ of these cases are symptomatic, usually involving pain and discomfort, particularly associated with strenuous activities, a unilateral bugle may appear, depending on the size of the hernia and the constitution of the patient ${ }^{2}$. Most patients are men, indeed, they are 25 times more likely to develop an inguinal hernia than women. This has traditionally been attributed to the fact that men have a larger inguinal canal that facilitated the descent of the testes in the prenatal period.

\section{DisCUSSION}

Inguinal hernias usually contain small intestine and omentum, however, other organs and organ parts, such as appendix, sigmoid colon, cecum, ovaries and urinary bladder may also be seen. The most frequent representative of the urinary tract is the bladder, present in $1-4 \%$ of all inguinal hernias, mostly direct ones ${ }^{3}$. Ureter, on the other hand, is a rare finding, described in only about 140 cases in the last 140 years. It is possible that it is underreported as it usually causes no symptoms and presents as an incidental finding. The condition is more common in transplanted patients, particularly if the grafted ureter is too long, or if it crosses over, rather than under the spermatic cord ${ }^{4,5}$. The ureter may be involved in femoral hernia as well, although two times less

\section{CASE PRESENTATION}

A 60 year old male patient with a history of kidney transplantation, recently elevated creatinine levels and suspected hydronephrosis, was admitted for a CT urography. Due to the elevated creatinine level $(152 \mu \mathrm{mol} / \mathrm{L})$ unenhanced CT scan was performed (Figure 1 and Figure 2). The enlarged transplant (13 cm long) was relived in the right iliac fossa, with dilated pyelon and calyxes, without parenchymal reduction, thus establishing the diagnosis of grade III (moderate) hydronephrosis. A dilated proximal ureter was observed, incarcerated and folded within inguinal hernia. In the distal portion of the ureter only filiform flow was detected. The patient did not report any symptoms regarding inguinal hernia. He was treated with hemodialysis 7 years prior the transplantation 9 years

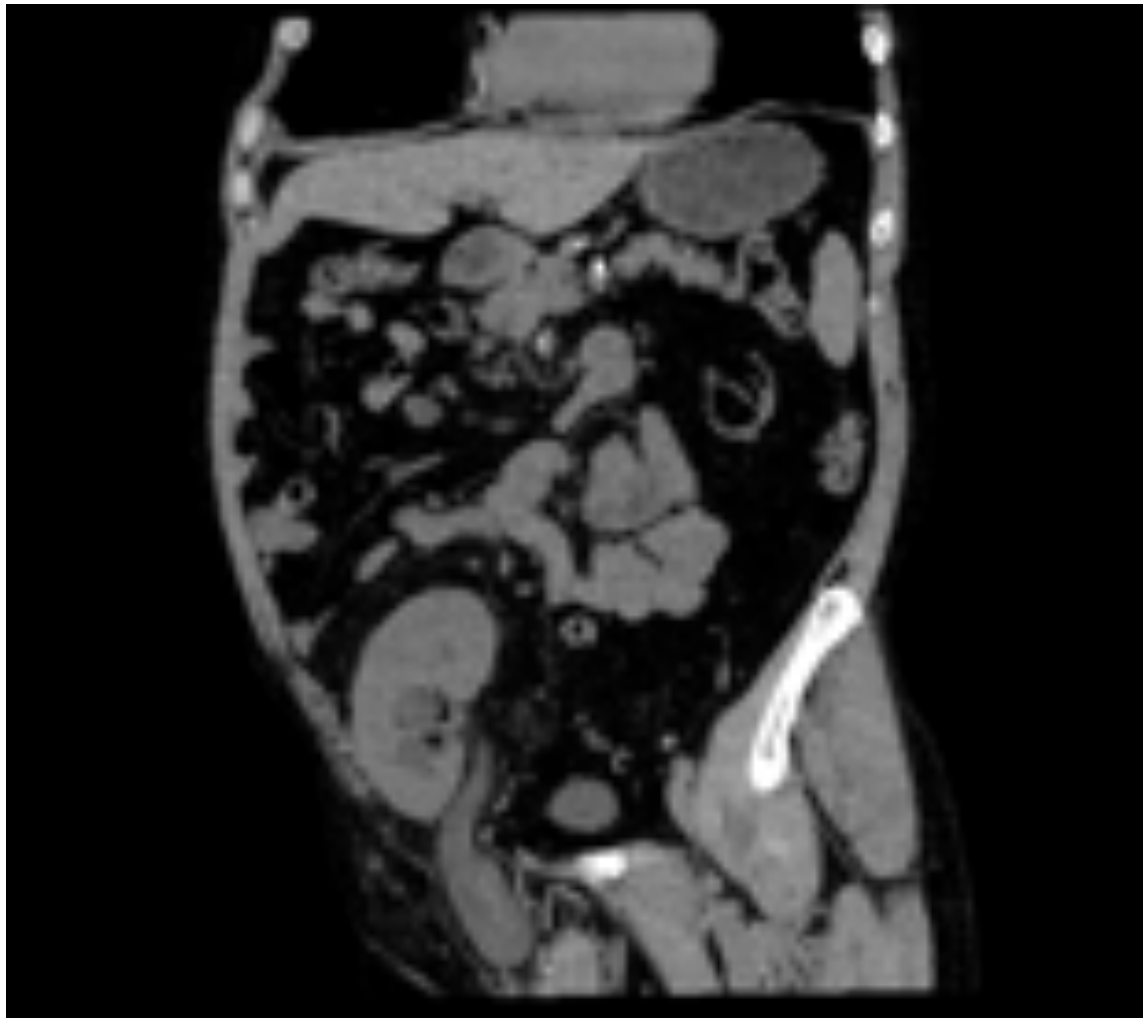

Figure 1. CT scan in coronal plane showing incarcerated ureter inside hernia sac on the right. ago due to the endemic nephrop-

athy. Additionally, he suffers from stable angina, hypertension and prostate hypertrophy. He also underwent parathyroidectomy 8 years ago and had coronary artery bypass graft after an infarction 6 years ago. Subsequent laboratory findings were in accordance with imaging results: C-reactive protein was $1.4 \mathrm{mg} / \mathrm{L}$, urea was elevated to 11.5 $\mathrm{mmol} / \mathrm{L}$ and creatinine $152 \mu \mathrm{mol} / \mathrm{L}$. The rest of the findings were inconspicuous. Surgical treatment was proposed to the patient, however, he was disinclined. Later control examinations reported stable grade of hydronephrosis and preserved kidney function probably due to the intermittent nature of ureteral incarceration. likely than in inguinal hernias. Just as regular inguinal hernias, ureteroinguinal hernias occur mostly in overweight men over 50 years of age. They are usually indirect $(80 \%)$ and on the right side ${ }^{6}$. The main reason for this is the fascia of Toldt, which secures and fixes the ureter in the retroperitoneum on the left. There are two types of ureteroinguinal hernia: paraperitoneal and extraperitoneal. The first, associated with kidney transplants, is believed to be acquired, due to the adhesions which attach ureter to the peritoneum that then drags it into hernial $\operatorname{sac}^{5}$. Extraperitoneal type is less common and presumably a result of congenital defect due to failed separation of ureteric bud from the Wolffian duct which leads to their joint migration to the scrotum. This kind of developmental anomaly is often associated with other anoma- 


\section{Case Report}

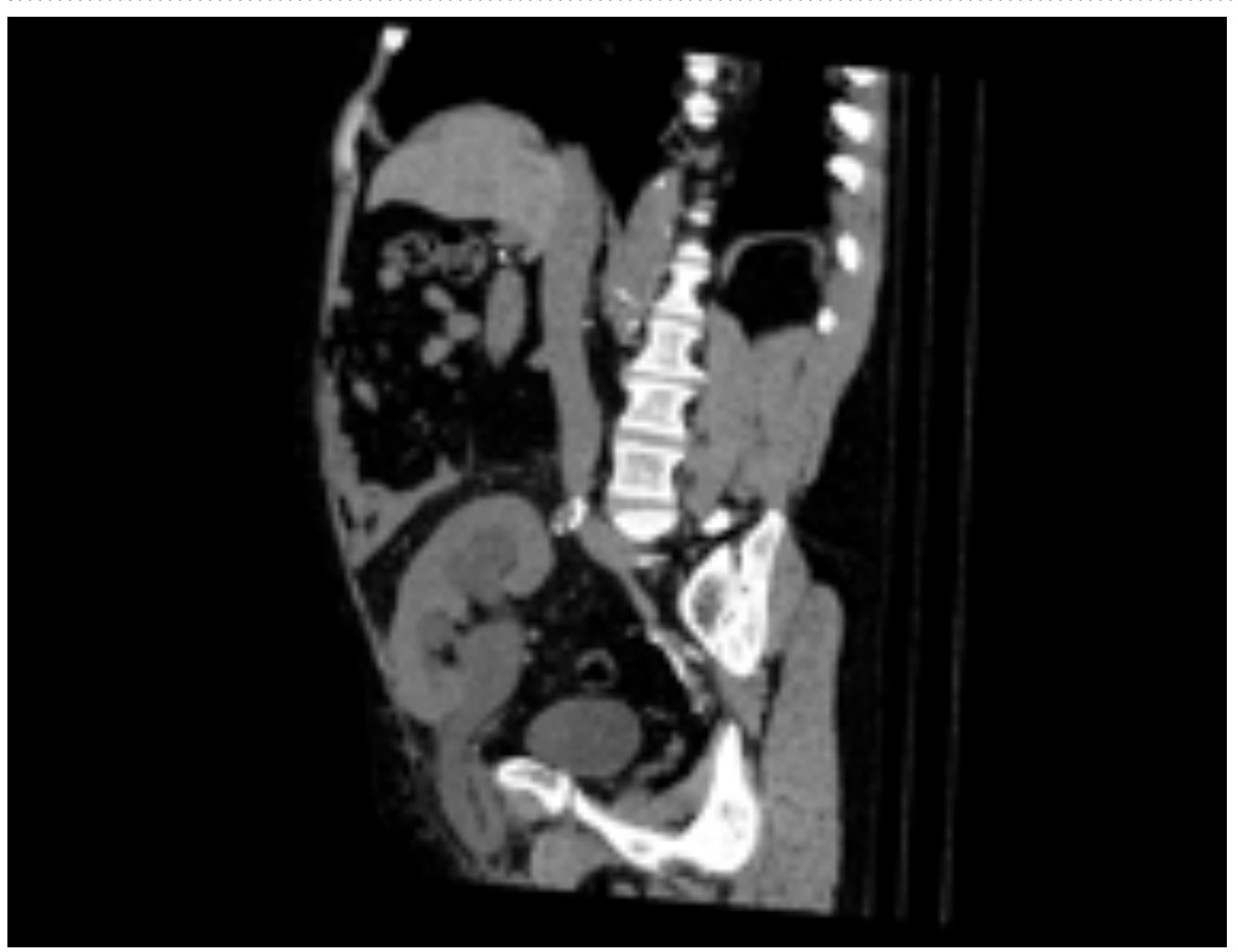

Figure 2. CT scan in sagittal plane

showing incarcerated ureter and enlarged kidney with third grade hydronephrosis of the transplanted kidney.

lies and, if detected, it should prompt the search for other anomalies and vice versa ${ }^{4}$.

The importance of proper diagnosis of ureteroinguinal hernias lies in their ability to cause hydronephrosis and in the possibility of ureteral injury during surgical treatment of hernia with overlooked ureter. The rate of reporting ureteroinguinal hernias has improved in the last years and many new cases provide interesting insights into this matter. One such case reported a bilateral obstructive uropathy caused by extrinsic inguinal hernia compressing both ureters without their involvement in the hernial sac itself'. The other described potentially useful hint for quick assessment of the probability of abnormalities in ureteral course on CT scans; namely, if the mid portion of the ureter lies anterior to the psoas muscle by more than $1 \mathrm{~cm}$ at the level of L4, the chances are there is something unusual in the distal portion ${ }^{8}$.

\section{CONCLUSION}

To conclude, we would like to remind our colleges to look for uretroinguinal hernias in overweight men, especially with transplanted kidneys, developing hydronephrosis. Also, it is necessary to exclude the involvement of the ureter in every inguinal hernia destined for operation.

\section{AUtHOR CONTRIBUTIONS:}

All authors listed have made a substantial, direct and intellectual contribution to the work, and approved it for publication.

\section{LITERATURE:}

1. Jenkins JT, O’Dwyer PJ. Inguinal hernias. BMJ. 2008;336(7638):269-272. doi:10.1136/bmj.39450.428275.AD

2. Fitzgibbons RJ Jr. Forse, RA. Groin hernias in adults. The New England Journal of Medicine. 19 February 2015. 372 (8): 756-63. doi:10.1056/NEJMcp1404068

3. Khan K, Chaudhry A, Feinman MB. Inguinoscrotal hernia containing the urinary bladder. BMJ Case Reports 2016;2016:bcr2016217408.

4. Epps JC, Close TP. Extraperitoneal herniation of the ureter. Applied Radiology. March-April 2019. (43-45)

5. Yahya Z, Al-habbal Y, Hassen S. Ureteral inguinal hernia: an uncommon trap for general surgeons. BMJ Case Reports 2017;2017:bcr2017219288.

6. Sidiqi MM, Menezes G. Asymptomatic herniation of ureter in the routine inguinal hernia: A dangerous trap for general surgeons. Int J Surg Case Rep. 2018;49:244-246. doi:10.1016/j.ijscr.2018.07.013 7. Grice PT, Nkwam N. Inguinal hernia causing extrinsic compression of bilateral ureters leading to chronic obstructive uropathy, Journal of Surgical Case Reports, Volume 2018, Issue 4, April 2018, rjy062, https://doi.org/10.1093/jscr/rjy062

8. Allam ES, Johnson DY, Grewal SG, Johnson FE. Inguinoscrotal herniation of the ureter: Description of five cases. International Journal of Surgery Case Reports. Volume 14, 2015, Pages 160-163 